Community Health Study/Study of Latinos. Am J Respir Crit Care Med 2021;203:356-365.

2. Sweetman A, Lack L, Bastien C. Co-Morbid Insomnia and Sleep Apnea (COMISA): prevalence, consequences, methodological considerations, and recent randomized controlled trials. Brain Sci 2019;9:371.

3. Sweetman AM, Lack LC, Catcheside PG, Antic NA, Chai-Coetzer $\mathrm{CL}$, Smith SS, et al. Developing a successful treatment for co-morbid insomnia and sleep apnoea. Sleep Med Rev 2017;33:28-38.

4. Zhang Y, Ren R, Lei F, Zhou J, Zhang J, Wing Y-K, et al. Worldwide and regional prevalence rates of co-occurrence of insomnia and insomnia symptoms with obstructive sleep apnea: a systematic review and meta-analysis. Sleep Med Rev 2019;45:1-17.

5. Edwards BA, Redline S, Sands SA, Owens RL. More than the sum of the respiratory events: personalized medicine approaches for obstructive sleep apnea. Am J Respir Crit Care Med 2019;200: 691-703.

Copyright @ 2021 by the American Thoracic Society

Check for updates

\section{Erratum: A Note on Common Apathy versus Hypoactive Delirium in Critical IIIness}

There are errors in the letter by Schieveld and colleagues (1), published in the April 1, 2021, issue of the Journal. Two references were omitted from the published version of the article:

Hermus IP, Willems SJ, Bogman AC, Brabers L, Schieveld JN. "Delirium" is no delirium: on type specifying and drug response. Crit Care Med 2015;43:e589.

Park SY, Lee HB. Prevention and management of delirium in critically ill adult patients in the intensive care unit: a review based on the 2018 PADIS guidelines. Acute Crit Care 2019;34:117-125.

These should have appeared as Reference 8 and 10, respectively. The Journal has replaced the online version of the letter with a corrected version in which the in-text citation numbers have been corrected throughout.

\section{Reference}

1. Schieveld JNM, Strik JJMH. A note on common apathy versus hypoactive delirium in critical illness [letter]. Am J Respir Crit Care Med 2021;203:921-923.

Copyright (C) 2021 by the American Thoracic Society

\section{Check for updates}

\section{Erratum: Positive End-Expiratory Pressure, Pleural Pressure, and Regional Compliance during Pronation: An Experimental Study}

Because of an error by the compositor, the print version of the article by Katira and colleagues (1), published in the May 15, 2021, issue of the Journal, contains some incorrect author affiliations. The errors were restricted to the listing of the participating units associated with the University of Toronto. Here is the corrected listing:

${ }^{2}$ Interdepartmental Division of Critical Care Medicine,

${ }^{4}$ The Institute of Medical Science, ${ }^{5}$ Department of Physiology,

${ }^{14}$ Department of Medicine, ${ }^{15}$ Institute for Health Policy, Management, and Evaluation, ${ }^{17}$ Department of Critical Care Medicine, Hospital for Sick Children, and ${ }^{18}$ Department of Anesthesia, Hospital for Sick Children, University of Toronto, Toronto, Ontario, Canada.

These affiliations are listed correctly in the article as published online, which is the version of record.

\section{Reference}

1. Katira BH, Osada K, Engelberts D, Bastia L, Damiani LF, Li X, Chen H, Yoshida T, Amato MBP, Ferguson ND, Post M, Kavanagh BP, Brochard LJ. Positive end-expiratory pressure, pleural pressure, and regional compliance during pronation: an experimental study. Am J Respir Crit Care Med 2021;203:1266-1274.

Copyright (C) 2021 by the American Thoracic Society
aThis article is open access and distributed under the terms of the Creative Commons Attribution Non-Commercial No Derivatives License 4.0 (https://creativecommons.org/licenses/by-nc-nd/4.0/). For commercial usage and reprints, please contact Diane Gern (dgern@thoracic.org).
aThis article is open access and distributed under the terms of the Creative Commons Attribution Non-Commercial No Derivatives License 4.0 (https://creativecommons.org/licenses/by-nc-nd/4.0/). For commercial usage and reprints, please contact Diane Gern (dgern@thoracic.org). 